\title{
PENGEMBANGAN PETUNJUK PRAKTIKUM KIMIA BERBASIS POGIL (Process Oriented Guided Inquiry Learning) BERMUATAN SWH (Science Writing Heuristic) PADA MATERI STOIKIOMETRI KELAS X DI MA FUTUHIYYAH 2 MRANGGEN DEMAK
}

\author{
Siti Zumronah ${ }^{1}$, R. Arizal Firmansyah ${ }^{2}$, dan Muhammad Zammi ${ }^{3}$ \\ ${ }^{1}$ MA Futuhiyyah 2 Mranggen Demak \\ ${ }^{2,3}$ Jurusam Pendidikan Kimia, FST, UIN Walisongo Semarang, Indonesia
}

\begin{abstract}
The research on the development of SWH-based POGIL chemical practicum instructions was based on the characteristics of students who liked practicum. However, practicum instructions are used like recipe books, so they have not been able to direct students to find material concepts. This study aims to determine the characteristics and quality of POGIL-based SWH-based chemical practicum guidance that can direct students to find material concepts. The POGIL-based SWH-based practicum instructions were developed using a 4-D development model which consisted of defining, designing, developing, and disseminating. However, what is done in this study is only limited to the development stage. The subjects of this study were 9 students from MA Futuhiyyah 2 Mranggen Demak with different levels of understanding. The characteristics of the chemical practicum instructions developed include: 1) practicum instructions arranged in stages (orientation, exploration, concept discovery, application, and closing) that can direct students to find concepts, 2) questions in detailed practical instructions and associated with the real life of students. The evaluation of the quality of POGIL-based SWH-based chemical practice manuals uses expert validation and student responses. The results of the validation assessment of material experts got a very good category $(S B)$ with a percentage of $92.3 \%$, while the assessment of media experts got a very good category $(S B)$ with a percentage of $90.83 \%$. The response of students to practicum instructions shows a very good category $(S B)$ with a percentage of $84.2 \%$. Thus it can be said that the POGIL-based SWH-based practicum guidelines are worthy of being used as guidelines for practicum implementation in the Laboratory and need to be further tested in large classes to find out the effectiveness of products in learning.
\end{abstract}

Keywords: Practicum Instructions, POGIL, Stoikiometri 


\begin{abstract}
Abstrak
Penelitian pengembangan petunjuk praktikum kimia berbasis POGIL bermuatan SWH ini didasarkan pada karakteristik peserta didik yang menyukai praktikum. Namun, petunjuk praktikum yang digunakan seperti buku resep, sehingga belum mampu mengarahkan peserta didik menemukan konsep materi. Penelitian ini bertujuan untuk mengetahui karakteristik dan kualitas petunjuk praktikum kimia berbasis POGIL bermuatan SWH yang dapat mengarahkan peserta didik menemukan konsep materi. Petunjuk praktikum berbasis POGIL bermuatan SWH dikembangkan dengan menggunakan model pengembangan 4-D yang terdiri dari tahap define (pendefinisian), design (perancangan), development (pengembangan), dan disseminate (penyebaran). Akan tetapi yang dilakukan dalam penelitian ini hanya terbatas pada tahap development. Subjek penelitian ini adalah 9 peserta didik dari MA Futuhiyyah 2 Mranggen Demak dengan tingkat pemahaman berbeda. Karakteristik dari petunjuk praktikum kimia yang dikembangkan antara lain: 1) Petunjuk praktikum disusun dengan tahapantahapan (orientasi, eksplorasi, penemuan konsep, aplikasi, dan penutup) yang dapat mengarahkan peserta didik menemukan konsep, 2) pertanyaanpertanyaan dalam petunjuk praktikum bersifat rinci dan dikaitkan dengan kehidupan nyata peserta didik. Penilaian kualitas petunjuk praktikum kimia berbasis POGIL bermuatan SWH menggunakan validasi ahli dan respon peserta didik. Hasil penilaian validasi ahli materi mendapat kategori sangat baik (SB) dengan persentase 92,3\%, sedangkan penilaian ahli media mendapat kategori sangat baik (SB) dengan persentase 90,83\%. Respon peserta didik terhadap petunjuk praktikum menunjukkan kategori sangat baik (SB) dengan persentase $84,2 \%$. Dengan demikian dapat dikatakan bahwa petunjuk praktikum berbasis POGIL bermuatan SWH layak digunakan sebagai panduan pelaksanaan praktikum di Laboratorium dan perlu diuji lebih lanjut pada kelas besar untuk mengetahui keefektifan produk dalam pembelajaran.
\end{abstract}

Kata kunci: Petunjuk Praktikum, POGIL, Stoikiometri

\title{
PENDAHULUAN
}

Praktikum merupakan salah satu metode pembelajaran yang berpusat pada peserta didik. Dalam pembelajaran praktikum, peserta didik dituntun untuk melakukan suatu alur percobaan, membuktikan hipotesis serta menyimpulkan hasil percobaan untuk memperoleh suatu kebenaran (Mufarrokah, 2009). Kegiatan praktikum mampu melatih peserta didik untuk berpikir dan bersikap ilmiah serta memahami konsep-konsep kimia (Firmansyah, 2012).

Salah satu materi kimia yang dapat disajikan dengan praktikum adalah materi stoikiometri. Stoikiometri merupakan bagian dari ilmu kimia yang mempelajari aspek kuantitatif kimia (Winarni, dkk, 2013). Berdasarkan hasil penelitian Agung dan Marc (2007), rata-rata peserta didik memiliki pemahaman yang relatif rendah pada 
stoikiometri yang berhubungan dengan konsep-konsep dasar kimia. Hal ini sejalan dengan hasil wawancara terhadap guru kimia di MA Futuhiyyah 2 yang mengatakan bahwa stoikiometri merupakan materi kimia yang paling sulit di kelas $\mathrm{X}$ yang dibuktikan dengan nilai rata-rata di bawah KKM setiap kali guru melakukan evaluasi. Selain itu, penyampaian materi stoikiometri membutuhkan jam pelajaran yang lebih banyak dan pembelajaran lebih berpusat kepada guru sehingga peserta didik cenderung pasif dan bosan dalam mengikuti pembelajaran yang berdampak pada rendahnya hasil belajar tersebut.

Berdasarkan hasil penyebaran angket menunjukan bahwa peserta didik lebih menyukai pembelajaran melalui praktikum dikarenakan peserta didik menjadi aktif dan dapat terlibat langsung dalam menyelesaikan permasalahan, sehingga peserta didik akan lebih mudah memahami materi yang dipelajari. Pembelajaran praktikum yang dilakukan di MA Futuhiyyah 2 terbatas pada materi larutan elektrolit-nonelektrolit, laju reaksi, sifat koligatif larutan, dan sistem koloid, sedangkan praktikum pada materi stoikiometri belum pernah dilakukan karena keterbatasan waktu .

Pelaksanaan praktikum membutuhkan sarana prasarana yang memadahi, seperti ketersediaan laboratorium, alat dan bahan, serta panduan praktikum atau petunjuk praktikum. MA Futuhiyyah 2 memiliki laboratorium yang berisi alat dan bahan lengkap. Namun, Petunjuk praktikum yang digunakan di MA Futuhiyyah 2 belum mampu menuntun peserta didik dalam menemukan konsep. Petunjuk praktikum yang digunakan terkesan seperti buku resep masakan yang mencantumkan secara lengkap tujuan; alat dan bahan; serta prosedur kerjanya, sehingga pada pelaksanaan praktikum peserta didik hanya mengikuti prosedur kerja tanpa mengetahui maksud dan tujuan yang terkandung. Petunjuk praktikum berbentuk seperti buku resep juga ditemukan di sekolah-sekolah lain. Salah satunya di SMA Malang. Nugroho (2013) menyatakan bahwa kebanyakan sekolah SMA di Malang menggunakan petunjuk praktikum yang menyerupai buku resep. Peserta didik hanya perlu melakukan langkah-langkah yang terdapat dalam petunjuk praktikum dan bersifat verifikatif.

Permasalahan tersebut jika dibiarkan akan menjadikan peserta didik pasif dalam setiap percobaan dan memiliki kemampuan rendah dalam menemukan konsep. Oleh karena itu diperlukan petunjuk praktikum yang dapat membimbing peserta didik dalam menemukan konsep. Salah satunya adalah dengan menerapkan model pembelajaran 
berbasis POGIL (Process Oriented Guided Inquiry Learning). POGIL merupakan model pembelajaran yang berorientasi proses dan berpusat pada peserta didik (student ecured) (Hele dan Linda, 2009; Widyaningsih, S.Y dkk, 2012), sehingga memunginkan mereka terlibat aktif secara kooperatif dalam proses pembelajaran (Widiawati, 2013). Tahapan-tahapan dalam POGIL disusun berdasarkan siklus belajar meliputi orientasi, eksplorasi, penemuan konsep, aplikasi, dan penutup, yang menuntun peserta didik menemukan sendiri konsep pengetahuan dan menuntun mereka untuk lebih kritis serta tanggap terhadap permasalahan yang dihadapi, sehingga pengetahuan yang mereka dapatkan akan lebih mendalam dan berkesan (Hanson, 2005). Berdasarkan hasil penelitian yang dilakukan Hale dan Linda (2009), pembelajaran POGIL dapat membuat peserta didik termotivasi dan aktif dalam mengikuti pembelajaran serta meningkatkan kinerja peserta didik dalam berdiskusi dan bertanggung jawab sesuai peranan masingmasing. Selain itu, pembelajaran POGIL berpengaruh terhadap prestasi belajar peserta didik (Widyaningsih, 2012), meningkatkan kemampuan berpikir kritis pada mata pelajaran fisika (Ningsih dkk, 2012) dan mengembangkan hubungan positif dengan peserta didik lain (Hanson, 2006).

Penerapan model pembelajaran POGIL dalam petunjuk praktikum akan membantu peserta didik dalam melakukan praktikum. Peserta didik yang awalnya pasif akan menjadi lebih aktif dan partisipatif, karena peserta didik dilibatkan langsung dalam setiap tahapan, mulai dari mendiskusikan pemecahan suatu masalah, merancang percobaan hingga mengerjakan soal aplikasi. Menurut Schroeder dan Greenbow (2008), penerapan model pembelajaran POGIL dapat mengubah persepsi peserta didik terhadap kimia organik, yang awalnya dianggap sulit menjadi mudah. Dengan demikian, diharapkan penerapan model pembelajaran POGIL dalam petunjuk praktikum kimia dapat mengubah persepsi peserta didik yang awalnya menganggap stoikiometri sulit menjadi mudah, sehingga dapat meningkatkan prestasi belajar peserta didik.

Petunjuk pratikum POGIL yang akan dikembangkan berisi 5 tahapan, meliputi: Orientasi, Eksplorasi, Penemuan Konsep, Aplikasi dan Penutup. 1) Tahap Orientasi berisi apersepsi yang memotivasi peserta didik untuk memunculkan minat dan rasa ingin tahu terhadap materi yang dipelajari. Apersepsi yang disajikan berupa fenomena kehidupan sehari-hari yang dipadukan dengan materi yang dipelajari sebagai prasyarat awal untuk menuju pemahaman konsep. 2) Tahap eksplorasi berisi serangkaian masalah 
yang disesuaikan dengan tujuan pembelajaran yang ingin dicapai. Masalah yang disajikan berisi petunjuk yang memberikan kesempatan bagi peserta didik untuk merancang suatu percobaan dan mengusulkan hipotesis. 3) Tahap penemuan konsep berisi pertanyaan-pertanyaan yang menuntun peserta didik untuk berpikir kritis dan analisis. Pertanyaan-pertanyaan tersebut disusun beruntun yang berfungsi untuk mengarahkan peserta didik dalam menemukan konsep. 4) Tahap aplikasi berisi pertanyaan-pertanyaan yang dihubungkan dengan fenomena kehidupan sehari-hari. Pertanyaan tersebut berfungsi untuk memperkuat dan memperluas konsep yang telah diperoleh peserta didik. 5) Tahap Penutup berisi refleksi, penilaian diri, dan penilaian teman sejawat sebagai umpan balik dari pembelajaran yang telah dilakukan.

POGIL yang digunakan dalam proses praktikum diadopsi dari POGIL yang dilakukan dalam proses pembelajaran di kelas (Hanson, 2005). Ketika diterapkan dalam media cetak berupa petunjuk praktikum harus disesuaikan dengan format pembuatan laporan praktikum. Menurut teori konstruktivis, penulisan laporan praktikum bertujuan untuk menjembatani pengetahuan sebelumnya dengan pembelajaran yang baru (Keys et al., 1999 dalam Erkol et al., 2010). Tetapi dalam format laporan praktikum tradisional, peserta didik diminta untuk menyelesaikan bagian seperti judul, tujuan, langkah kerja, analisis data dan pembahasan yang memverifikasi konsep sains yang disampaikan guru. Situasi demikian tidak mampu membuat peserta didik berpikir kritis dan menemukan konsep materi yang sedang dipelajari. Salah satu format laporan praktikum yang dapat digunakan untuk membantu peserta didik menemukan konsep adalah format laporan praktikum SWH (Science Writing Heuristic).

SWH merupakan modifikasi dari format laporan tradisional (Firmansyah, 2012). Modifikasi tersebut bertujuan untuk membiasakan peserta didik berpola pikir sebagaimana ilmuwan yang menyelesaikan suatu permasalahan dengan melakukan proses penyelidikan dan pengkajian hasil penyelidikan di laboratorium, sehingga dapat mempermudah peserta didik dalam menemukan konsep (Erkol et al., 2010). Format SWH didasarkan pada siklus pembelajaran dimana peserta didik mengeksplorasi konsep untuk mencari pola dan memverifikasi hasil yang diharapkan (Schroeder and Greenbowe, 2008). Format SWH juga dapat meningkatkan kemampuan argumentasi ilmiah peserta didik (Kumala, 2017)

SWH yang diaplikasikan dalam petunjuk praktikum POGIL tercantum dalam 
beberapa bagian, diantaranya: 1) Judul percobaan yang berupa pertanyaan menggantung yang dapat mendorong peserta didik berpikir lebih kritis. 2) Hipotesis dan tinjauan hipotesis sebagai bahan refleksi peserta didik. 3) Format laporan praktikum yang mendorong peserta didik menemukan konsep materi. Berdasarkan latar belakang, maka perlu Pengembangan Petunjuk Praktikum Kimia Berbasis POGIL (Process Oriented Guided Inquiry Learning) Bermuatan SWH (Science Writing Heuristic) pada Materi Stoikiometi Kelas X di MA Futuhiyyah 2 Mranggen Demak.

\section{METODE PENELITIAN}

Penelitian ini menggunakan metode penelitian pengembangan (R\&D) Thiagarajan 4D yang dimodifikasi menjadi 3D (Define, Design, dan Develop). Tahap define terdiri dari 5 tahapan, yaitu analisis ujung depan, analisis karakteristik peserta didik, analisis tugas, analisis konsep, dan perumusan tujuan pembelajaran. Tahap design terdiri dari 3 tahapan yaitu pemilihan media, pemilihan format, dan pembuatan rancangan awal. Tahap develop terdiri dari validasi produk oleh ahli materi dan ahli media, serta uji lapangan produk yang dilakukan pada 9 peserta didik kelas XI di MA Futuhiyyah 2 Mranggen Demak. Teknik pengumpulan data yang digunakan dalam penelitian ini meliputi observasi, wawancara dan angket.

\section{HASIL DAN PEMBAHASAN}

Permasalahan dasar yang terjadi pada pembelajaran kimia antara lain: Stoikiometri merupakan materi tersulit di kelas $\mathrm{X}$ yang dibuktikan dengan nilai hasil ulangan peserta didik yang rata-rata di bawah KKM $(\mathrm{KKM}=75)$, proses pembelajaran hanya berpusat pada guru, sehingga kegiatan peserta didik dalam pembelajaran hanya sebatas mendengarkan guru menjelaskan materi yang mengakibatkan peserta didik cenderung pasif dan bosan dan petunjuk praktikum yang digunakan dalam memandu praktikum tidak dapat menuntun peserta didik menemukan konsep. Berdasarkan analisis masalah tersebut maka diperlukan media yang sesuai untuk proses pembelajaran. Media yang akan dikembangkan yaitu petunjuk praktikum berbasis POGIL bermuatan SWH pada materi stoikiometri yang mengadopsi POGIL menurut Hanson (2005) dan SWH. Hasil kualitas produk oleh ahli materi dan ahli media secara keseluruhan dapat dilihat pada Tabel 1 berikut: 
Tabel 1 Penilaian Ahli Validator Materi dan Media

\begin{tabular}{|l|c|c|c|}
\hline o. & Validator & $\begin{array}{c}\text { Skor } \\
\text { Keidealan }\end{array}$ & Kriteria \\
\hline & Ahli Materi & $92,3 \%$ & Sangat Baik \\
\hline & Ahli Media & $90,83 \%$ & Sangat Baik \\
\hline
\end{tabular}

Hasil penilaian validator ahli materi dalam aspek kelayakan isi mendapat kategori Sangat Baik (SB) dengan persentase 91,67\%, aspek kelayakan kebahasaan mendapat kategori Sangat Baik (SB) dengan persentase 93,33\%, kelayakan penyajian mendapat kategori Sangat Baik (SB) dengan presentase 90\%, aspek POGIL mendapat kategori Sangat baik (SB) dengan persentase 93,33\% dan penilaian laporan praktikum mendapat kategori Sangat Baik dengan persentase $86,67 \%$. Hasil penilaian Validator media pada aspek penyajian mendapat kategori Sangat Baik (SB) dengan persentase 93,33\%, aspek kelayakan kegrafikan mendapat kategori Sangat Baik dengan persentase 90\%, dan aspek kualitas tampilan mendapat kategori Sangat Baik (SB) dengan persentase 93,33\%.

Selain dari validasi ahli, penilaian kualitas petunjuk praktikum berbasis POGIL bermuatan SWH juga berdasarkan angket respon pengguna (peserta didik). Berdasarkan analisis respon peserta didik diperoleh penilaian dengan rata-rata sangat baik (SB). Hasil rekapitulasi angket respon peserta didik selengkapnya disajikan pada Tabel 2.

Tabel 2. Rekapitulasi Angket Respon Peserta didik

\begin{tabular}{|l|l|c|c|}
\hline No. & \multicolumn{1}{|c|}{ Aspek penilaian } & \% Keidealan & Kriteria \\
\hline 1 & Kemudahan memahami & 85,60 & Sangat Baik \\
\hline 2 & Penemuan konsep & 74,40 & Baik \\
\hline 3 & Desain petunjuk praktikum & 84,80 & Sangat Baik \\
\hline 4 & Keterlaksanaan praktikum & 86,70 & Sangat Baik \\
\hline 5 & Format laporan praktikum & 84,00 & Sangat Baik \\
\hline
\end{tabular}

Pemilihan model pembelajaran POGIL bermuatan SWH pada pengembangan petunjuk praktikum dikarenakan pada model tersebut menggabungkan proses inkuiri terbimbing dan pembelajaran kooperatif yang mampu membuat peserta didik terlibat aktif dalam proses pembelajaran. Menurut Schoeder dan Greenbow (2008), penerapan 
model pembelajaran POGIL di kelas dan penerapan SWH di laboratorium dapat mengubah persepsi peserta didik terhadap kimia organik yang dianggap sulit menjadi mudah. Menurut Sani, dkk (Wawancara, 17 Desember 2018), dengan menggunakan petunjuk praktikum berbasis POGIL bermuatan SWH sebagai panduan praktikum dapat membantu peserta didik dalam menemukan konsep materi dengan cara menjawab pertanyaan-pertanyaan menuntun dan konseptual yang disajikan. Kemudian Syafa dan Shofiyatul (Wawancara, 17 Desember 2018), menjelaskan bahwa dengan menggunakan petunjuk praktikum berbasis POGIL bermuatan SWH dapat menuntun peserta didik merancang praktikum yang akan dilakukan. Mereka mengaku dengan merancang praktikum sendiri mereka menjadi lebih paham dengan maksud dari tahapan-tahapan yang mereka kerjakan dalam praktikum.

Penggunaan petunjuk praktikum berbasis POGIL bermuatan SWH dapat mengubah persepsi peserta didik yang awalnya menganggap stoikiometri sulit menjadi mudah. Hal ini sesuai pemaparan Candra, Rada dan Uswatun (Wawancara, 17 Desember 2018) yang mengatakan bahwa stoikiometri ketika di kelas X terasa sulit, namun setelah melakukan praktikum dengan petunjuk praktikum berbasis POGIL bermuatan SWH mereka menjadi lebih paham dan mereka mengakui bahwa ternyata stoikiometri tidak sesulit di kelas X.

\section{SIMPULAN}

Kesimpulan yang dapat diambil pada penelitian ini adalah sebagai berikut:

1. Karakteristik petunjuk praktikum berbasis POGIL bermuatan SWH meliputi:

a. Petunjuk praktikum disusun dengan tahapan-tahapan yang dapat menuntun peserta didik menemukan konsep. Tahapan-tahapan tersebut meliputi orientasi, eksplorasi, penemuan konsep, aplikasi dan penutup.

b. Pertanyaan-pertanyaan dalam petunjuk praktikum bersifat rinci dan dikaitkan dengan kehidupan nyata peserta didik.

2. Kualitas petunjuk praktikum kimia berbasis POGIL bermuatan SWH berdasarkan penilaian ahli materi mendapatkan kategori sangat baik (SB) dengan presentase 92,3\%, penilaian ahli media mendapatkan kategori sangat baik (SB) dengan presentase $90,83 \%$, dan berdasarkan respon peserta didik mendapatkan kategori 
sangat baik (SB) dengan presentase $84,2 \%$. Hal ini menunjukkan bahwa petunjuk praktikum kimia berbasis POGIL bermuatan SWH layak digunakan dalam pelaksanaan praktikum di laboratorium dan dikategorikan sangat baik (SB). 


\section{DAFTAR PUSTAKA}

Agung, Salamah \& Marc S. Schwartz. (2007). Students' Understanding of Conservation of Matter, Stoichiometry and Balancing Equations in Indonesia. Internation Journal of Science Education, 29:13, 1679-1702. Canada: McGill University

Chang, Raymond. (2004). Kimia Dasar Edisi 3 Jilid 1. Jakarta: Gramedia

Erkol, Mehmet, et al., (2010). The Effect of Implementation of Science Writing Heuristic on Students' Achievement and Attitudes toward Laboratory in Introductory Physics Laboratory. Procedia Social and Behavioral Sciences 2 (2010) 2310-2314

Firmansyah, R. Arizal. (2012). Implementasi Process Oriented Guided Inquiry Learning (POGIL) dalam Perkuliahan dan Science Writing Learning (SWH) dalam Praktikum: Telaah Peranan Pendidikan Kimia dalam Mensukseskan Green Chemistry. IAIN Walisongo Semarang: Tadris Kimia

Hale, Dena dan Linda Greef Mullen. (2009). Designing Process-Oriented GuidedInquiry Activities: A New Innovation for Marketing Classes. Marketing Education Review, Volume 19, Number 1

Hanson, David M. (2005). Designing Process-Oriented Guided-Inquiry Activities. Stony Brook University: Department of Chemist

Schoeder, Jacob D. and Thomas J. Greenbowe. (2008). Implementing POGIL in the Lecture and The Science Writing Heuristic in The Laboratory-Student Perceptions and Performance in Undergraduate Organic Chemistry. Chem.Educ.Res.Pract.2008, Vol. 9, Number 149-156

Sugiyono. (2017). Metode Penelitian Pendidikan (Pendekatan Kuantitatif, Kualitatif, dan $R \& D)$. Bandung: Alfabeta

Sugiyono. (2013). Cara Mudah Menyusun: Skripsi, Tesis, dan Desertasi. Bandung: ALfabeta

Sugiyono. (2012). Statistika untuk Penelitian. Bandung: Alfabeta

Widoyoko, Eko Putro. (2009). Evaluasi Program Pembelajaran. Yogyakarta: Pustaka Pelajar 